\title{
Digital skills for workplace mentors in construction sector apprenticeships (CONDAP)
}

\author{
Javier Cárcel-Carrasco ${ }^{a}$, Elisa Peñalvo-López ${ }^{b}$ Jaime Llinares-Millán'; Manuel \\ Valcuende-Payád \\ ${ }^{a}$ Universitat Politècnica de València. Email: fracarc1@ csa.upv.es \\ ${ }^{\mathrm{b}}$ Universitat Politècnica de València. Email: elpealpe@upvnet.upv.es \\ ${ }^{\mathrm{c}}$ Universitat Politècnica de València. Email: jllinares@csa.upv.es \\ ${ }^{\mathrm{d}}$ Universitat Politècnica de València. Email: mvalcuen@csa.upv.es
}

\begin{abstract}
Employers in the construction industry are regularly and increasingly reporting hiring difficulties, since the sector is experiencing a skills shortage in spite of numerous apprenticeship schemes. According to the European Construction Sector Observatory, the main reason of this skills shortage is two-fold: a) the inadequacy of VET provision, and b) the low attractiveness of the sector to young people, further hindered by the perception of its limited capacity for innovation. Correspondingly, modernising construction apprenticeships is crucial for the development of key skills and the improvement of the employability of young construction workers. Training the trainers and mentors to become more engaged and involved in the design of apprenticeships and to introduce new methods, digital tools, and innovative content during their teaching practices is essential to make training more flexible and effective. Such an approach could effectively address the misalignment between VET offerings and the demand for skills and innovation in the construction sector. This article shows the focus of the European project CONDAP, whose purpose is to improve learning in the construction sector.
\end{abstract}

Keywords: Self-learning; Construction site managers; Specific training; Efficient learning. 


\section{Introduction}

Apprenticeship trainers and mentors, particularly in the construction sector, often appear reluctant to change their ways of teaching and introduce new methods and/or tools during their teaching practices, for reasons related to either their priorities or time constraints. It many cases, trainers and especially mentors' management skills, pedagogical capabilities, and ability to design and carry out a project with apprentices are insufficiently developed. Moreover, they may be facing somewhat increased fears (compared to other sectors) of being substituted by technology; this is especially true for new digital technologies (e.g. use of self-learning/self-paced mobile applications), which are usually not very attractive for senior teachers and trainers (Cárcel \&Peñalvo, 2016; QPID, 2000; James, 2003; Fuller, 2005; McDonald, 2007).

Lacking support from digital solutions and tools, apprenticeships are not adequately individualised and flexible, and VET curricula often are delayed in supporting the shift in skills needed for new methods in construction. To this end, key actors for adopting training innovations, namely in-company mentors and trainers, need to improve their own skills through the adoption of digital tools and innovative methods. It is also interesting to introduce knowledge to analyze sustainability in energy scenarios in construction (Peñalvo \& Cárcel, 2017; CEDEFOP, 2012).

CONDAP is in an EU-funded project with the objective to enhance the digital skills of mentors in construction apprenticeships, funded by the Erasmus+ programme for the period 2018-2021 (Web 1; Web 2).

\section{Expected outcomes Condap}

The project aims to enhance the quality and value of apprenticeships in the sector by upgrading the training of workplace trainers / mentors with an innovative methodological approach, digital training resources, and tools that will:

a) Increase trainers' flexibility and effectiveness (e.g. choose when and how they train, focus on facilitation and not on checking for errors in the performance of learners, foster ICT-based peer to peer learning),

b) Improve their monitoring \& assessment capacity and individual approach towards learners, and

c) Allow mentors to readily respond to the modernisation of the construction sector. 


\section{Expected outcomes:}

- An analysis of the current and future training needs of workplace trainers and mentors in the construction sector apprenticeships that would enable them to offer quality training to workers in the construction sector.

- Definition of learning outcomes and learning units for workplace trainers and mentors focused on the use of innovative, digital tools.

- Development of openly available (OERs) digital training material and instructions for workplace trainers and mentors in the construction sector.

- Validation of the developed training course by members of the target group in each partnership country.

- Promotion and dissemination of the produced training resources in the European construction sector.

\section{Target groups:}

- Construction sector workplace trainers/mentors

- Employers in the construction sector

- VET providers for construction workers participating in apprenticeships

- Apprentices in the construction sector

- Representatives and associations of employers and employees in the construction sector

- Policy makers/ Regulators or related bodies

\section{Partnership}

The partnership comprises of 5 partners with high capacity, qualifications and complementary skills from the world of VET and employment, with direct links to apprenticeships, to align mentors' training with specific labour market needs and apprenticeship particularities and meet requirements in terms of efficiency, innovation, and timely implementation.

- INSTRUCTUS is the Lead Partner and specialises in the development of apprenticeship programmes and is the sole issuing authority for Apprenticeship Frameworks for the Building Services Engineering sector; it has the potential to guide work-based training development in the sector and the technical capacity to handle funded projects.

- Vocational Advancement Service of the Construction Industry Association of BerlinBrandenburg (BFW), as an experienced provider of educational services specialised for the construction industry, operating 3 VET centres, brings unique experience in designing VET 
curricula addressing the construction sector needs and previous knowledge in apprenticeship training. Furthermore, it is experienced in European initiatives targeting the skills mismatch in construction apprenticeships.

- University Polytechnic of Valencia (UPV) carries specialised R\&D and has expertise in OERs; it offers specialised knowledge on digital opportunities in the construction industry and is experienced in the implementation of ERASMUS+ projects.

- Hellenic Society for the Promotion of Research \& Development Methodologies (PROMEA) has extensive experience in R\&D and implementation of research and training activities, being an expert in the development of innovative ICT-based methodologies for learning and training. The organisation is experienced in managing in ERASMUS+ projects for the improvement of workforce skills.

- European Builders Confederation (EBC) represents occupational interests at EU level and brings access to the views of construction companies, providing valuable insights into actual digital skills requirements for workplace mentors. It has extensive experience in EU projects addressing the construction sector and VET innovation and is involved in the blueprint for the construction sector; thus undertakes lobbying and dissemination activities.

INSTRUCTUS and BFW are newcomers to the Action. However, the Lead Partner's staff has extensive experience in relevant ERASMUS+ projects and the organisation is a successor of companies involved in similar projects. BFW has been engaged in European initiatives addressing training-of-trainers on sustainable construction. Both organisations will internationalise and enrich their training activities with CONDAP resources.

The partnership formation will combine partners' complementary expertise to address the particular challenges related to the professionalization of mentors in construction apprenticeships, following a systematic, European VET approach.

\section{Overview of project outputs, activities, and events}

The following list provides an overview of the intellectual outputs and multiplier events of the CONDAP project, which will be described in detail in section G:

1. Evidence based learning outcomes for the professional development of workplace mentors in construction sector apprenticeships that will be exploited to upskill mentors with digital skills and competences and innovative teaching practices $(\mathrm{O} 1)$.

2. VET learning units for mentors as trainers participating in construction apprenticeships, focusing on energy efficiency, sustainability and digitalisation of 
construction, and innovative pedagogical orientations for learning and teaching digital construction methods $(\mathrm{O} 2)$.

3. Open Education Resources (OERs) and Vocational Open Online Course (VOOC) infrastructures supporting the professional development and training of in-company mentors which are engaged in modernised apprenticeship schemes in the construction sector (O3).

4. Pilot testing for the validation of CONDAP learning materials and open online course and the exploitation of project materials as best practices for VET of workplace mentors in construction sector apprenticeships (O4).

5. Development of a systematic approach to support the enhancement of the digital skills of mentors in construction sector apprenticeships, targeting the integration of CONDAP learning outcomes into VET (O4).

6. Two (2) demonstration workshops in UK and Germany to validate CONDAP learning materials and VOOC and promote the project's key results to in-company mentors, employers and VET providers in the construction sector $(\mathrm{E} 1, \mathrm{E} 2)$.

7. Three (3) national information days Spain, Greece and Belgium to share and disseminate CONDAP results and to inform in-company mentors, VET providers and construction companies (employers) about the project outcomes and the added value of the developed knowledge resources (E3, E4, E5).

\section{Most relevant topics addressed:}

- $\quad$ ICT - new technologies - digital competences

- New innovative curricula/educational methods/development of training courses

- Overcoming skills mismatches (basic/transversal)

\section{Outputs Condap}

Some of the main outputs of the condap project are:

\section{Output Identification - IO1}

Output Title

Evidence based learning outcomes for mentors in construction sector apprenticeships

Output description 
Development of learning outcomes for workplace mentors in construction sector, in order to address the current misalignment between VET trainings and the demand for skills in the construction sector.

The objective is to identify in-company mentors' training needs, taking into account the digital construction sector challenges, as the main drivers of skills needs (table 1).

Table 1. Tasks and description of output IO1

\begin{tabular}{|c|c|c|c|}
\hline code & Task & Description & Partners' involvement \\
\hline $\begin{array}{l}\text { O1- } \\
\text { T1 }\end{array}$ & $\begin{array}{l}\text { Methodology } \\
\text { and tools for } \\
\text { the collection } \\
\text { of evidence on } \\
\text { mentors' } \\
\text { digital skills } \\
\text { needs and } \\
\text { training } \\
\text { requirements }\end{array}$ & $\begin{array}{l}\text { This task regards the development of a } \\
\text { methodology and accompanying tools for } \\
\text { the identification of current and future } \\
\text { training requirements and digital skills } \\
\text { needs of workplace mentors in construction } \\
\text { apprenticeships. } \\
\text { It includes the description of information } \\
\text { gathering methods (field research and desk } \\
\text { research). }\end{array}$ & $\begin{array}{l}\text { PROMEA: Preparation and } \\
\text { drafting of research } \\
\text { methodology and fine-tuning } \\
\text { according to partners' feedback. } \\
\text { Development of accompanying } \\
\text { tools for information collection. } \\
\text { All partners except } \\
\text { INSTUCTUS: Translation of } \\
\text { information collection tools in } \\
\text { own language. }\end{array}$ \\
\hline $\begin{array}{l}\text { O1- } \\
\text { T2 }\end{array}$ & $\begin{array}{l}\text { Identification } \\
\text { of digital skills } \\
\text { needs and } \\
\text { training } \\
\text { requirements } \\
\text { of mentors in } \\
\text { the } \\
\text { construction } \\
\text { sector }\end{array}$ & $\begin{array}{l}\text { a) Field research that will comprise one } \\
\text { online survey among construction } \\
\text { companies and employers' representatives } \\
\text { that will result to the mapping of } \\
\text { employers' skills needs in construction } \\
\text { sector } \\
\text { b) Desk research on digital construction } \\
\text { methods will also be used for the collection } \\
\text { of information on workplace mentors } \\
\text { training } \\
\text { requirements. }\end{array}$ & $\begin{array}{l}\text { INSTRUCTUS: Coordination of } \\
\text { task, desk research, coordination } \\
\text { of field research and } \\
\text { compilation of collected } \\
\text { information from all partner } \\
\text { countries. Data collection in } \\
\text { own country } \\
\text { All partners: Data collection in } \\
\text { own country and provision of } \\
\text { input for desk research }\end{array}$ \\
\hline $\begin{array}{l}\text { O1- } \\
\text { T3 }\end{array}$ & $\begin{array}{l}\text { Development } \\
\text { of CONDAP } \\
\text { learning } \\
\text { outcomes }\end{array}$ & $\begin{array}{l}\text { This task will yield a report which will } \\
\text { define and present CONDAP learning } \\
\text { outcomes as drawn from the training needs } \\
\text { analysis of the data and information } \\
\text { gathered in O1-T2. The report will } \\
\text { elaborate on the skills related to the digital } \\
\text { construction } \\
\text { The objective is to upskill mentors with (a) } \\
\text { digital professional skills and (b) improved } \\
\text { teaching practices. }\end{array}$ & $\begin{array}{l}\text { INSTRUCTUS: Analysis of } \\
\text { data and information gathered in } \\
\text { O1-T2 and drafting of the } \\
\text { CONDAP learning outcomes } \\
\text { report } \\
\text { BFW \& UPV: Contribution in } \\
\text { defining learning outcomes } \\
\text { PROMEA \& EBC: Provision of } \\
\text { feedback }\end{array}$ \\
\hline
\end{tabular}

\section{Output Identification - IO2}

Output Title

CONDAP learning units and teaching methodology for mentor as trainers

Output description

Development of CONDAP learning units is the basis upon which the VOOC will be developed (table 2). Learning units will correspond to the outcomes specified in the context of $\mathrm{O} 1$. The thematic areas will cover digital construction methods related to a) energy 
efficiency / sustainable construction and b) digitalisation of construction. This output will also deliver specific guidelines for the course exploitation in the context of apprenticeships; and the development of a methodology for teaching the use of digital construction methods in the context of apprenticeships.

Table 2. Tasks and description of output IO2

\begin{tabular}{|c|c|c|c|}
\hline code & Task & Description & Partners' involvement \\
\hline $\begin{array}{l}\mathrm{O} 2- \\
\mathrm{T} 1\end{array}$ & $\begin{array}{l}\text { Clustering of } \\
\text { learning } \\
\text { outcomes into } \\
\text { CONDAP } \\
\text { learning units }\end{array}$ & $\begin{array}{l}\text { This task will cluster the defined } \\
\text { learning outcomes into learning } \\
\text { units, referring to thematic subject } \\
\text { areas, such as the following: } \\
\text { 1: Energy efficiency and sustainable } \\
\text { construction } \\
\text { 2: Digitalisation of construction } \\
\text { 3: Other construction practices } \\
\text { transforming the industry } \\
\text { 4: Organisational, management and } \\
\text { communication skills. } \\
\text { This output will yield a specialised } \\
\text { training curriculum and will set the } \\
\text { basis for the development of the } \\
\text { learning units in the context of O2- } \\
\text { T2. }\end{array}$ & $\begin{array}{l}\text { BFW: Development of the training } \\
\text { curriculum based on learning } \\
\text { outcomes } \\
\text { INSTRUCTUS \& UPV: } \\
\text { Contribution to the development of } \\
\text { the training curriculum } \\
\text { PROMEA \& EBC: Provision of } \\
\text { feedback }\end{array}$ \\
\hline $\begin{array}{l}\mathrm{O} 2- \\
\mathrm{T} 2\end{array}$ & $\begin{array}{l}\text { Development of } \\
\text { CONDAP } \\
\text { learning units for } \\
\text { construction } \\
\text { apprenticeships }\end{array}$ & $\begin{array}{l}\text { This output builds on the training } \\
\text { curriculum created in the context of } \\
\text { O2-T2 and regards content } \\
\text { development of CONDAP learning } \\
\text { units. } \\
\text { The learning units will translated in } \\
\text { the languages of the partnership. }\end{array}$ & $\begin{array}{l}\text { UPV: Development of the learning } \\
\text { units. Drafting of a report presenting } \\
\text { the specifications \& characteristics. } \\
\text { Content translation in own language } \\
\text { INSTRUCTUS: Contribution to the } \\
\text { development of learning units. } \\
\text { Review and Provision of input. Fine- } \\
\text { tuning of learning units after their } \\
\text { evaluation. } \\
\text { BFW, PROMEA, EBC: Review and } \\
\text { Provision of input. Content } \\
\text { translation in own language. }\end{array}$ \\
\hline $\begin{array}{l}\mathrm{O} 2- \\
\text { T3 }\end{array}$ & $\begin{array}{l}\text { Innovative } \\
\text { pedagogical } \\
\text { orientations for } \\
\text { learning and } \\
\text { teaching digital } \\
\text { construction } \\
\text { methods and } \\
\text { tools }\end{array}$ & $\begin{array}{l}\text { This output will deliver an } \\
\text { innovative methodology for the } \\
\text { course exploitation in the context of } \\
\text { apprenticeships by mentors-as- } \\
\text { trainers, so as to enrich the teaching } \\
\text { ability of in-company mentors. }\end{array}$ & $\begin{array}{l}\text { BFW: Development of the } \\
\text { innovative teaching methodology for } \\
\text { mentors and drafting of the relevant } \\
\text { report } \\
\text { INSTRUCTUS: Contribution to the } \\
\text { development of the innovative } \\
\text { teaching methodology for mentors } \\
\text { and drafting of the relevant report } \\
\text { UPV, PROMEA, EBC: Review and } \\
\text { provision of input }\end{array}$ \\
\hline
\end{tabular}




\section{Output Identification - IO3}

Output Title

Development of CONDAP Vocational Open Online Course (VOOC) for workplace mentors in construction apprenticeships, based on Open Educational Resources

Output description

This output includes the adaptation of CONDAP learning units into Open Educational Resources (OERs) and consequently the development of Vocational Open Online Course (VOOC) infrastructures, that will support the professional development of in-company mentors (table 3).

Table 3. Tasks and description of output IO3

\begin{tabular}{|c|c|c|c|}
\hline code & Task & Description & Partners' involvement \\
\hline $\begin{array}{l}\text { O3- } \\
\text { T1 }\end{array}$ & $\begin{array}{l}\text { Adaptation of } \\
\text { CONDAP } \\
\text { learning units } \\
\text { into Open } \\
\text { Educational } \\
\text { Resources } \\
\text { (OERs) }\end{array}$ & $\begin{array}{l}\text { The task includes the development of } \\
\text { openly available digital training } \\
\text { resources and materials (videos, slide } \\
\text { presentations, FAQs, audiovisual } \\
\text { aids), corresponding to CONDAP } \\
\text { learning outcomes and units. } \\
\text { All learning material will be available } \\
\text { online as OER and will be translated } \\
\text { in the languages of the partnership. }\end{array}$ & $\begin{array}{l}\text { INSTRUCTUS: Coordination of the } \\
\text { activity, creation of educational } \\
\text { resources and fine-tuning according to } \\
\text { the results of the validation. } \\
\text { UPV: Co-develop CONDAP OERs. } \\
\text { Translation of materials in own } \\
\text { language. } \\
\text { BFW, PROMEA, EBC: Translation of } \\
\text { materials in own language. }\end{array}$ \\
\hline $\begin{array}{l}\text { O3- } \\
\text { T2 }\end{array}$ & $\begin{array}{l}\text { Creation of } \\
\text { additional } \\
\text { learning } \\
\text { material for the } \\
\text { CONDAP } \\
\text { Vocational } \\
\text { Open Online } \\
\text { Course } \\
\text { (VOOC) }\end{array}$ & $\begin{array}{l}\text { The deliverable regards the creation } \\
\text { of additional pedagogical resources to } \\
\text { be incorporated in the VOOC (video } \\
\text { units, work assignments, collaboration } \\
\text { mechanisms that will also be openly } \\
\text { available to learners). }\end{array}$ & $\begin{array}{l}\text { PROMEA: Provide guidelines for the } \\
\text { creation of additional resources for the } \\
\text { VOOC. Translation of materials in own } \\
\text { language. } \\
\text { INSTRUCTUS: Creation of additional } \\
\text { resources for the VOOC } \\
\text { BFW: Contribute to the creation of } \\
\text { additional resources for the VOOC. } \\
\text { Translation of materials in own } \\
\text { language. } \\
\text { UPV, EBC: Translation of materials in } \\
\text { own language. }\end{array}$ \\
\hline $\begin{array}{l}\mathrm{O} 3- \\
\mathrm{T} 3\end{array}$ & $\begin{array}{l}\text { Development } \\
\text { of CONDAP } \\
\text { Vocational } \\
\text { Open Online } \\
\text { Course } \\
\text { (VOOC) } \\
\text { infrastructure } \\
\text { for mentors in } \\
\text { construction } \\
\text { apprenticeships }\end{array}$ & $\begin{array}{l}\text { This task includes the technical and } \\
\text { functional preparation of the } \\
\text { CONDAP VOOC (which will } \\
\text { comprise the CONDAP learning } \\
\text { units, as well as the contextualised } \\
\text { training materials produced in O3-T1, } \\
\text { O3-T2). } \\
\text { Development of the VOOC } \\
\text { infrastructures includes: a) the } \\
\text { identification \& selection of suitable } \\
\text { VOOC providers to host the online } \\
\text { course and b) the development of the } \\
\text { VOOC structure and functionalities. } \\
\text { Initial testing of the VOOC within the } \\
\text { partnership and provision of feedback } \\
\text { is also foreseen in this activity. }\end{array}$ & $\begin{array}{l}\text { PROMEA: Identification of suitable } \\
\text { platforms to host VOOC infrastructures } \\
\text { and content, development of VOOC } \\
\text { structure \& functionalities, creation of } \\
\text { descriptive materials in English. } \\
\text { Development of VOOC structure and } \\
\text { functionalities in the five languages of } \\
\text { the partnership (EN, DE, ES, GR, FR). } \\
\text { Facilitate the operation of the VOOC } \\
\text { accounting for the technical aspects. } \\
\text { Development of evaluation forms and } \\
\text { drafting of the final report on the } \\
\text { testing outcome. Fine-tune the VOOC. } \\
\text { INSTRUCTUS, BFW, UPV, EBC: } \\
\text { Testing of the VOOC and complete } \\
\text { evaluation form. Online promotion of } \\
\text { the VOOC. }\end{array}$ \\
\hline
\end{tabular}




\title{
Output Identification - IO4
}

\author{
Output Title
}

Validation of the digital skills and the open online course for workplace mentors in construction sector apprenticeships and exploitation activities

Output description

The purpose of this output is to develop an EU strategic partnership to promote and facilitate the valorisation and exploitation of project materials as best practices for VET of workplace mentors in construction sector apprenticeships, in order to exploit the project learning outcomes and the VOOC in the context of a more systematic approach (table 4)..

Table 4. Tasks and description of output $\mathrm{IO4}$

\begin{tabular}{|c|c|c|c|}
\hline Code & Task & Description & Partners' involvement \\
\hline O4-T1 & $\begin{array}{l}\text { Methodology for } \\
\text { the validation of } \\
\text { CONDAP } \\
\text { learning materials }\end{array}$ & $\begin{array}{l}\text { The task involves the definition of } \\
\text { methodology and tools for the pilot-testing } \\
\text { and the validation of CONDAP learning } \\
\text { materials and open online course, the } \\
\text { methods for collecting feedback and } \\
\text { guidelines for the drafting of the validation } \\
\text { report. }\end{array}$ & $\begin{array}{l}\text { PROMEA: Preparation of the } \\
\text { validation methodology. } \\
\text { All partners: Review of the } \\
\text { methodology }\end{array}$ \\
\hline $\mathrm{O} 4-\mathrm{T} 2$ & $\begin{array}{l}\text { Pilot testing of } \\
\text { the CONDAP } \\
\text { learning materials } \\
\text { and open online } \\
\text { course }\end{array}$ & $\begin{array}{l}\text { This task regards pilot testing of the } \\
\text { CONDAP learning materials and VOOC: } \\
\text { (a) in the context of running construction } \\
\text { apprenticeships in the UK and Germany. } \\
\text { Mentors will be trained using the VOOC, } \\
\text { the CONDAP learning materials and } \\
\text { teaching methodology. Consequently they } \\
\text { will apply acquired knowledge into their } \\
\text { existing apprenticeship schemes for } 1 \\
\text { month. Finally, they will be asked to } \\
\text { provide feedback on their CONDAP train- } \\
\text { the-trainer } \\
\text { (b) by other members of target groups in } \\
\text { the partnership countries. Testers will be } \\
\text { granted access to the CONDAP course } \\
\text { remotely and will be asked to complete an } \\
\text { online questionnaire to provide feedback. }\end{array}$ & $\begin{array}{l}\text { INSTRUCTUS, BFW: Pilot } \\
\text { testing in running } \\
\text { construction apprenticeships } \\
\text { and feedback collection. } \\
\text { EBC: Pilot testing in the } \\
\text { partnership countries } \\
\text { (remotely) and feedback } \\
\text { collection. } \\
\text { PROMEA: Coordination of } \\
\text { the activity and collection of } \\
\text { results. } \\
\text { UPV: Mobilise contacts to } \\
\text { participate to the pilot } \\
\text { testing. }\end{array}$ \\
\hline O4-T3 & $\begin{array}{l}\text { CONDAP } \\
\text { learning materials } \\
\text { validation results } \\
\text { and guidelines for } \\
\text { valorisation }\end{array}$ & $\begin{array}{l}\text { This output will yield the validation report } \\
\text { analysing the results of the pilot-run and } \\
\text { presenting conclusions on the validation of } \\
\text { the learning materials and the open online } \\
\text { course for workplace mentors. } \\
\text { Furthermore, the activity includes a road- } \\
\text { map for the exploitation of the project } \\
\text { results, focusing on suggestions for the } \\
\text { systematic use and integration of CONDAP } \\
\text { learning outcomes into VET. }\end{array}$ & $\begin{array}{l}\text { PROMEA: Drafting of the } \\
\text { validation report } \\
\text { INSTRUCTUS: Drafting of } \\
\text { the road-map for systematic } \\
\text { integration of CONDAP } \\
\text { outcomes into VET. } \\
\text { EBC: Co-drafting of the } \\
\text { road-map (industry related } \\
\text { aspects) } \\
\text { INSTRUCTUS, BFW, UPV: } \\
\text { Review validation report. }\end{array}$ \\
\hline
\end{tabular}




\section{Multiplier Events:}

CONDAP demonstration workshops:

Organisation of one-day workshops in partners' countries for the demonstration and dissemination of the learning materials and the VOOC to in-company mentors, employers and VET providers in the construction sector.

Participants: in-company mentors, representatives of construction companies hiring apprentices, VET providers.

CONDAP national infodays:

Organisation of one-day infoday in partners' countries to inform the target audience (incompany mentors involved in construction apprenticeships, VET providers, construction companies) about CONDAP, the project outcomes and the added-value of the developed knowledge resources.

\section{Conclusions}

The European project CONDAP aims to improve learning in the construction sector.

According to the European Construction Sector Observatory, the main reason of this skills shortage is two-fold: a) the inadequacy of VET provision, and b) the low attractiveness of the sector to young people, further hindered by the perception of its limited capacity for innovation.

Employers in the construction industry are regularly and increasingly reporting hiring difficulties, since the sector is experiencing a skills shortage in spite of numerous apprenticeship schemes.

Correspondingly, modernising construction apprenticeships is crucial for the development of key skills and the improvement of the employability of young construction workers. Training the trainers and mentors to become more engaged and involved in the design of apprenticeships and to introduce new methods, digital tools, and innovative content during their teaching practices is essential to make training more flexible and effective. 


\section{Acknowledgment}

This work has been conducted within the framework of the CONDAP project "Digital skills for workplace mentors in construction sector apprenticeships" funded by the European Commission within the Key Action 2: Cooperation for innovation and the exchange of good practices, reference number 2018-1-UK01-KA202-048122.

\section{References}

Cárcel-Carrasco, J. \& Peñalvo-Lopez, E. (2016) "Training in smart metering technologies for construction site managers". Congreso INNODOCT 2016 (Valencia). Editorial UPV. 223-256

Fuller A, Beck V, Unwin L (2005), “The Gendered Nature of Apprenticeship Employers' and Young People's Perspectives”, Education And Training, Vol. 47 No. 4/5, 2005, pp. 298-311.

James, D, Diment, K. (2003) "Going Underground? Learning and assessment in an ambiguous space”, Journal of Vocational Education and Training 55 (4) 407-422.

McDonald, S., Erickson, L.D., Kirkpatrick Johnson, M. and Elder (2007) "Informal Mentoring and Young Adult Employment". Social Science Research. 36: 1328-47.

Peñalvo López; E; Cárcel Carrasco, J; et al.. (2017) A Methodology for Analysing Sustainability in Energy Scenarios. Sustainability. 9, pp. 1590-1601. 2017. ISSN 2071-1050. DOI: 10.3390/su9091590.

QPID (2000) Mentoring for Work-Based Training, Department for Education and Employment at http://scottishmentoringnetwork.co.uk/assets/downloads/resources/

MentoringforWorkbasedTrainingStudyReport.pdf.

Web1. CONDAP Project. https://ec.europa.eu/programmes/erasmus-plus/projects/eplus-projectdetails/\#project/2018-1-UK01-KA202-048122

Web 2. EUROPEAN COMMISSION. The EU programme for education, training, youth and sport. < https://ec.europa.eu/programmes/erasmus-plus/node_es. 